her pain. She was asked to go on taking gradual deep breaths followed by complete expiration. This allowed the operator's fingers good access down into the pelvic cavity. The breech was taken out of the pelvis and into the superior strait. Once this was accomplished the rest was not difficult. The breech was pushed out and up towards the back of the foctus and the head in and down towards the child's abdomen. A few movements like this were necessary to get the head into the iliac fossa. Then the patient was asked to turn a little to the side opposite to that in which the back of the foetus was lying. When this was done the head was pushed inwards and downwards and the breech lifted upwards. The head was felt passing over the brim into the pelvic inlet. The dorsal position was then resumed and the head was gripped between the fingers and pushed down into the pelvic cavity. This last manœuvre gave us an idea of the size of the pelvis. Once the head was in the pelvis the version was complete. Occasionally it was necessary to push the breech towards the child's abdomen and the head towards its back, the child turning by anti-clockwise movement. Pushing out the breech from the pelvic cavity by the help of fingers introduced in the vagina was also occasionally required. No binder or any other appliance was found necessary to maintain the vertex position.

The patient was asked to report two days later, and was kept under observation subsequently. If at any later visit reversal to a breech position was noticed another attempt at cephalic version was made. More than two attempts were never found necessary, and that, too, in a very small number of cases. We did not meet with any untoward complications due to the manipulations.

I cannot conclude without expressing my thanks to my house-surgcons Drs. Jhavery and Shah.

REFERENCES

Barncy (1934). Year Book of Obstetrics and Gynaecology, p. 47. Bourne, A. (1933). Qucen Charlotle's Textbook of Obstetrics, p. 316 .

Cannell, D. E., and Dodck, S. M. (1934). Amer. J. Obstet. Gynec., 27, 517.

Dearnley, G. (1931). British Medical Journal, 2, 371.

Donovan, H. C. E. (1933). Ycar Book of Obstetrics and Gynaeco$\log y, \mathrm{p} .19 \mathrm{i}$

Geothals, T. R. (1936). Surg. Gynec. Obstet., 62, 525

Gibberd, G. F. (1931). British Medical Journal, 2, 369.

Gordon, C. A.. Garlick, R., and Oginz, P. (1934). Amer. J. Obstet. Ginec., 28, 140.

Holland, E. (1932). Reccnt Adrances in Obstetrics and Gynaeco$\log y$, p. 47.

Kedar Nath Das (1926). Textbook of Midwifery, p. 150.

Kerr. Munro (1933). Mtaternal Mortality and Morbidity, pp. 112, 189.

King, E. L., Gladden, A. H. (1929). Amer. J. Obstet. Gynec., i 7,78 .

McCullagh, W. McK. H. (1933). British Medical Journal, 2, 646.

Morton, D. G. (1932). Amer. J. Obstet. Gynec., 24, 853.

Pierson, R. N. (1923). Surg. Ginec. Obstet., 37, 802.

Ryder, G. H. (1923). Ibid., 37, 660.

Studdiford, W. E. (1932). J. Amer. med. Ass., 99, 1820.

Westman, A. (1931). J. Obstet. Gynaec. Brit. Emp.. 38, 696.

Williams, W. (1924) Obstetrics, New York, p. 323

Wilson, J. St.G. (1930). J. Obstet. and Gynaec. Brit. Emp., 37, 858

Wrigley, A. J. (1934). British Medical Journal, 1, 891.

A special tour in Central Europe has been arranged for May 23 to June 10 in connexion with the meeting at Bucarest of the Permanent Committee of the International Congress of Military Medicine and Pharmacy. Leaving Paris on May 23 at 10.15 p.m. the places to be visited include Venice, Dubrovnik, Cettigne, Serajevo, Belgrade, Turnu-Severin, and seven days in Bucarest. The fee of $£ 61$ 10s. covers all travel expenses from Paris to Bucarest and back with second-class rail travel with Wagons-lits and first-class passages on river boats and various excursions on the way. An alternative return journey through Budapest and Vienna, extending over June 10 to 16 , can be made for $f 7$. For further details and for booking application should be made to Gellatly, Hankey and Co. Ltd., 62, Pall Mall, London, S.W.1, or at the offices of this firm in Manchester, Liverpool, or Glasgow.

\section{A NEW STABILIZER FOR SCHICK TOXIN} BY

\section{A. T. GLENNY}

AND

\author{
MURIEL F. STEVENS \\ Wellcome Physiological Research Laboratories
}

The improvement in methods of making dilutions of diphtheria toxin used in the Schick test has steadily increased their stability during the past sixteen years, and now such dilutions remain unaltered for at least six to twelve months, or more, at room temperature. We have retested many batches that have been returned to us from such distant places as Bombay, Shanghai, Capetown, the Federated Malay States, and the Argentine. These dilutions have travelled by ordinary post or by air mail, and have always been of full strength when tested on their return. Recent papers, however, have shown that the present dilutions produce allergic reactions in a very small percentage of subjects. H. J. Parish (1936) summarizes fourteen such cases, including one with very severe reactions attributed to peptone, reported by $G$. Bousfield (1936). The possibility of producing with Schick toxin a severe allergic response to peptone has induced us to find another stabilizing agent free from this disadvantage. We propose for the purpose human serum.

\section{Experimental Work}

The strength of Schick toxin dilutions has been measured quantitatively at the Wellcome Physiological Research Laboratories by the determination of the minimal reacting dose in guinea-pigs and by titration against antitoxin (Glenny and O'Brien, 1921). Stability has been judged by tests made after exposure to higher temperatures than would be encountered during normal storage. As improvements have been made so we have increased the temperature by different stages from $30^{\circ} \mathrm{C}$. to $45^{\circ} \mathrm{C}$. Results of this rapid test for deterioration have always been confirmed by subsequent tests on material left for long periods at room temperature. In his pioneer work in this country on diphtheria immunization Dr. R. A. O'Brien used for the Schick test dilutions in saline containing 0.5 per cent. phenol, the common U.S.A. diluent. Such dilutions remained stable for a week at $15^{\circ} \mathrm{C}$. but retained only 5 to 15 per cent. their original strength after twentyfour hours at $35^{\circ} \mathrm{C}$. A few seconds' shaking in partially filled bottles caused total destruction (Glenny et al., 1925). Experimental work showed that a buffer solution increased the stability of toxin dilutions, and although a phosphate buffer was more suitable to use at the optimum $p \mathrm{H}$ for stability, a boric borate buffer (Glenny et al., 1928) of slightly higher $p \mathrm{H}$ was chosen for its bacteriostatic properties. Some batches of toxin diluted to Schick strength in buffer were more stable than others, remaining at full strength for fourteen weeks at room temperature, whereas others were only stable for four weeks. Weaker toxins needing less dilution were more stable than stronger toxins. Assuming that increased stability was due to a higher broth content, the next step was to increase the amount of broth in the dilution to 0.5 per cent. Such dilutions remained stable for six months at room temperature. Bunney (1931) suggested the use of 2 per cent. peptone. Experiments at these laboratories showed that 0.1 per cent. Witte peptone in borate buffer solution was sufficient to stabilize Schick toxin so that it would remain of full potency for twelve months or more at room temperature. 
We have chosen human serum as the stabilizer which is least likely to cause allergic reactions or to act as a sensitizer in human subjects. It is necessary to choose serum which does not contain enough antitoxin to interfere with the balance between the toxicity and combining power (antitoxin binding power) of the toxin. We have used serum containing no detectable antitoxin (that is, less than 0.0005 unit per c.cm.). The stability of Schick dilutions containing various amounts of human serum and of peptone is given in the table.

\begin{tabular}{|c|c|c|c|c|c|c|c|c|}
\hline & & & & cent & of $t$ & post & $\begin{array}{l}\text { to } 45^{\circ} \\
\text { Streng }\end{array}$ & \\
\hline & & & 1 & 2 & 3 & 7 & 14 & 28 \\
\hline $\begin{array}{c}\text { Boric bora } \\
\text { taining } \\
1 \text { in } 1,000\end{array}$ & $\begin{array}{l}\text { te } \\
\mathrm{w}\end{array}$ & $\begin{array}{l}\text { fer con- } \\
\text { peptone }\end{array}$ & 85 & 80 & 70 & 55 & 30 & 20 \\
\hline 1 in 1,000 & hu & serum & $<40$ & 20 & - & 0 & - & - \\
\hline 1 in 500 & " & ... & 75 & 60 & 45 & 25 & 10 & 0 \\
\hline 1 in 200 & " & ... & 70 & 70 & 45 & 40 & 20 & 0 \\
\hline 1 in 100 & " & $\ldots$ & 90 & 80 & 55 & 45 & 30 & 10 \\
\hline
\end{tabular}

Experience of all former diluents has shown that any material losing less than 40 per cent. of its potency after twenty-four hours at $45^{\circ} \mathrm{C}$. remains stable for at least six months at room temperature. We consider that 1 in 500 human serum will remain stable (that is, at least 80 per cent. of its original strength) for six months at room temperature. This is sufficient for all practical purposes, and although the toxin could be further stabilized by increasing the serum content to 1 in 100 this would involve the use of unnecessarily large amounts of human serum.

\section{Summary}

Dilutions of diphtheria toxin for use in the Schick test need a stabilizer.

Peptone has been used for this purpose, but has been reported to cause allergic reactions.

Human serum is shown by animal experiments to be a suitable substitute.

\section{REFERENCES}

Bousfield, G. (1936). Medical Officer, 56, 193.

Bunney, W. E. (1931). J. Immunol. 20, 71 .

Glenny, A. T., and O'Brien, R. A. (1921). Lancet, 1, 1236

Glenny, A. T., and O'Brien, R. A. (1921). Lancet, 1, 1236. 31, 133 .

$\overline{\text { Parish, H. J. (1936). }}$ and Wallace, U. (1925). Ibid., 28, 471.

According to K. Jaroschka (Zbl. Gynäk., January 9, 1937, p. 82) it is unwise in abdominal removal of large submucous myomata to attach too great importance to the preservation of the faculty of parturition. Numerous cases of uneventful spontaneous labour after myomectomy have been reported-for example, after enucleation of nine myomata during pregnancy, and after a conservative myoma operation in which the amnion was pierced by the sutures and liquor amnii subsequently discharged for twenty-four hours. Nevertheless, serious dangers to both mother and foetus may attend labour in the myomectomized uterus. In illustration Jaroschka records the case of a patient aged 39 who conceived eight months after abdominal removal of eight myomata (some being submucous) : going into labour in the ninth lunar month she had Caesarean section done on account of uterine inertia, the os being fully dilated. Operation showed that portions of the placenta were attached to two cicatricial areas (the sites of operative incisions) which were devoid of musculature. Delivery by the vaginal route would certainly have been attended by complete rupture of the uterus in the third if not the second stage of labour, for manual removal of the placenta would have been required.

\section{Clinical Memoranda}

\section{Migration and Excretion of a Foreign Body}

This unusual case is of interest because it demonstrates how Nature can occasionally deal with a situation in which surgery is powerless.

On September 24, 1936, a man aged 40 years, wishing to commit suicide, shot himself in the chest with a revolver. The bullet entered the left sixth intercostal space half an inch outside the left mid-clavicular line. A skiagram showed a foreign body lying in the midline and just anterior to the tenth thoracic vertebra.

The patient developed pneumonia, with a temperature of $102^{\circ}$. It was decided not to operate on account of the inaccessibility of the bullet and in view of the patient's poor general condition. Moreover, he had undergone a gastroenterostomy only two months before admission. Comment was made upon the fact that the bullet, although injuring the left lung, had apparently missed such vital structures as the heart and the larger blood vessels.

Thirteen days later, in the course of defaecation, the patient passed a foreign body in the stools. It was a bullet haif an inch in length. A subsequent skiagram showed no evidence of a foreign body, and the patient made a complete recovery.

Similar cases are rare. However, Evans (1931) reports the migration of a $5-\mathrm{cm}$. piece of metal from the abdominal wall. Operation for its removal was unsuccessful, and it was recovered from the stools four days later. He emphasizes the importance of taking a skiagram immediately before any attempt at removal, with special consideration to the migrating tendencies of foreign bodies.

For permission to record this case I wish to thank Dr. Edward Miles, medical superintendent of Oldchurch Hospital, Romford.

Romford. Anderson Garland, M.D., D.P.H.

REFERENCE

Evans, W. A. (1931). Amer. J. Roentgen., 25, 802.

\section{Temporary Post-traumatic Total Blindness}

The following unusual case may be of interest. A man aged 22 was admitted to this hospital recently. His history was as follows:

\section{CASE RECORD}

2.30 p.m.-He received a slight kick in the right frontal region while playing Rugby football, He felt dazed for a short time, but continued playing.

3.15 p.m.-He remembered picking up the ball and kicking it, and then he immediately became totally blind. He could not remember any second head injury, and was at no time unconscious.

5.15 p.m.- He was brought to the hospital, conscious, apparently feeling well and with no headache, but totally blind in the right eye, and with perception of light just returning in the left eye. The fundi showed marked swelling of the inner edge of both disks, especially the right; no retinal haemorrhage or exudate. Power, sensation, and reflexes were normal.

6 p.m.- He complained of slight right frontal headache. A small swelling, half-inch by half-inch, was developing on the right side of the forehead one inch above the orbit.

6.45 p.m.- - He could distinguish objects at less than three feet in the left eye, and could just appreciate light in the right eye. The papilloedema was very marked in the right eye, but unchanged in the left. He also complained for a short time of uncontrollable flickering of the right eyelid.

8 p.m.-Distant vision was returning to the left eye and light was now easily seen by the right eye. Papilloedema was diminished in the left eye, but increased in the right eye. The field of vision in the left eye, by rough tests, was complete. 